\title{
Quality of life and patient-reported outcomes following proton therapy for oropharyngeal carcinoma: a systematic review
}

\author{
${ }^{1}$ Noorazrul Yahya* \\ ${ }^{2}$ Hanani A. Manan
}

${ }^{1}$ Diagnostic Imaging and Radiotherapy, CODTIS, Faculty of Health Sciences, National University of Malaysia, Jalan Raja Muda Aziz 50300 Kuala Lumpur, Malaysia

2 Functional Image Processing Laboratory, Department of Radiology, Universiti Kebangsaan Malaysia Medical Centre, Cheras 56000 Kuala Lumpur, Malaysia

* Corresponding author

Number of tables: XX

Number of figures: $\mathrm{XX}$

Correspondence address:

Noorazrul Yahya

Faculty of Health Sciences

The National University of Malaysia

Jalan Raja Muda Aziz

50300 Kuala Lumpur Malaysia

Tel: +603-92897221

Email: azrulyahya@ukm.edu.my

Running Title: QOL following proton for oropharyngeal ca.

Keywords: quality of life, patient-reported outcomes, oropharyngeal carcinoma, proton therapy 
medRxiv preprint doi: https://doi.org/10.1101/2020.11.04.20226175; this version posted November 6, 2020. The copyright holder for this preprint

(which was not certified by peer review) is the author/funder, who has granted medRxiv a license to display the preprint in perpetuity.

All rights reserved. No reuse allowed without permission.

2

\section{Abbreviations}

PT - Proton therapy

PRISMA - Preferred Reporting Items for Systematic Reviews and Meta-Analyses 
medRxiv preprint doi: https://doi.org/10.1101/2020.11.04.20226175; this version posted November 6, 2020. The copyright holder for this preprint

(which was not certified by peer review) is the author/funder, who has granted medRxiv a license to display the preprint in perpetuity.

All rights reserved. No reuse allowed without permission.

\section{Compliance with Ethical Standards}

Funding: National University of Malaysia, GP-2019-K017963 (ukm.edu.my) to NY.

Conflict of Interest: Authors declare no conflict of interest.

Ethical approval: This article does not contain any studies with human participants performed by any of the authors.

\section{Data available on request from the authors}

The data that support the findings of this study are available from the corresponding author upon reasonable request. 


\section{ABSTRACT}

Background: Complex anatomy surrounding the oropharynx makes proton therapy (PT) especially intensity-modulated PT (IMPT) a good option due to its ability to reduce the volume of irradiated healthy tissues. Dosimetric improvement may not translate to clinically relevant benefit. As outcome data are emerging, we aimed to systematically review current evidence of the quality of life (QOL) and patient-reported outcomes (PRO) following PT of oropharyngeal carcinoma (OC).

Materials and Methods: We searched PubMed and Scopus electronic databases to identify eligible reports on QOL and PRO following PT of OC according to PRISMA guidelines. Reports were extracted for information on demographics, main results and clinical and dose factors correlates.

Results: Six reports were selected from which four compared between PT and photonbased therapy. All endpoints where significant differences were found favour PT. The change following treatment improves but never to the baseline level.

Conclusion: Available evidence suggests that PT causes less QOL deterioration and PRO compared to photon therapy. Whether or not it is cost-effective should be a subject of further investigation.

Keywords: proton therapy; oropharyngeal carcinoma; patient-reported outcomes, quality of life 


\section{INTRODUCTION}

Among patients treated for oropharyngeal carcinoma (OC), acute and late treatment-related sequelae including xerostomia, dysphagia and dysgeusia remain to be a challenge [1-3]. These consequences of treatment may impact the quality of life (QOL) including difficulties in communication, nutritional intake enjoyment and social contact [2]. Maintaining good QOL following OC is especially important now due to improved survivorship related to better treatment regime and improved prevalence of human papillomavirus (HPV)-related squamous cell carcinoma which disproportionately impacts young and physically fit individuals [4]. Thus, improving therapies to mitigate the occurrence of these treatment side effects is paramount.

As there are multitudes of studies which have empirically demonstrated the impact of dose distributions including to salivary glands [5-10], swallowing muscles [8-12], oral cavity [2] and other normal tissues to patient-reported outcomes (PRO) and quality of life (QOL) measures in photon-based therapy. Proton therapy (PT) offers several advantages over photon therapy in including the elimination of exit dose and the possibility to tailor the dose resulting from the physical characteristics of the beams with Bragg peaks [13, 14]. Several dose comparison studies have shown significant dose reduction favouring PT [15, $16]$

While dosimetric analyses have proven the benefits of PT based on dosimetric advantage $[17,18]$, PT is not without its challenges [19]. Deviation of the given dose distribution from the intended distribution due to uncertainties from intrafraction motion and patient set-up error is especially larger in pencil beam scanning technique. Furthermore, range uncertainties as a systematic error can be in the range between 3 to $3.5 \%$. Combining these two sources of errors result in the radiological path length of proton beams which are different from the intended length. While the simulation of radiation is highly accurate, the modelling of the human body based on CT images of the patient is not similarly precise due to the calibration uncertainties between the Hounsfield unit (HU) values and the proton stopping powers and intra- and interfractional variations in anatomy [20]. Beddok et al. in a review has outlined the challenges and how they can be at least partially overcome [20]. 
These errors are relevant to normal tissue effects as improved dose distribution may not necessarily improve PRO and QOL measures.

There appear to be a few reports presenting the actual impact of PT to PRO and QOL. The limited availability of PT in the past may be the reason for the sparse empirical evidence. Furthermore, some institutions prefer to assess toxicities based on physician-reported measures probably due to the historical emphasis on these measures. However, as more centres are offering PT and increasing interest to measure outcomes which are more patient-centred and connect to patients in a more meaningful way, we may see more clinical results especially involving PRO and QOL mature. In this study, we aimed to systematically review the PRO and QOL changes following PT of oropharyngeal carcinoma.

\section{MATERIALS AND METHODS}

\section{Systematic review protocol and eligibility criteria}

The systematic review protocol and methodology established by Preferred Reporting Items for Systematic Reviews and Meta-Analyses (PRISMA) was utilised [21-23]. Original research manuscripts were evaluated for inclusion or exclusion based on PICOS criteria detailed in Supplementary A. The PICOS framework is used to develop literature search strategies by systematically determine the inclusion based on patient population, intervention, comparison, outcome, and study design. Reports fulfilling all five criteria were included. Excluded studies were reported based on the first PICOS criterion not fulfilled.

\section{Search strategy and selection process}

Electronic databases (National Center for Biotechnology Information (PubMed) and Scopus) were searched to identify articles. Keywords used are detailed in Supplementary B. In the first phase, articles were reviewed in increasing specificity via the title, abstract, then finally, via full text by NY and HAM independently. In the second phase, bibliographic references, and citations of relevant studies in phase one were extracted from 
Scopus and hand searched for additional eligible studies based on the assumption that relevant studies cited or were cited by other related studies. We have confidence in the robustness of this two-step method to ensure no omission of relevant studies. No publication date or publication status restriction was imposed. Discrepancies in the results of the selection were deliberated in team meetings. Where more than one reports of a study existed, reports with a more complete result were included. Where an institution published multiple reports from the same patient cohort but with different endpoints, all reports were included. Study search and selection were completed in September 2020.

\section{Quality assessment}

We used an assessment tool from the National Heart, Lung and Blood Institute; Quality Assessment of Case-Control Studies to evaluate the quality of studies where comparisons were made to patients treated with photon therapy and Quality Assessment Tool for Observational Cohort and Cross-Sectional Studies to evaluate studies comparing outcomes to baseline measures.

\section{Data review and extraction}

Upon finalisation of article selection, data extraction was performed by NY. Information was extracted into spreadsheets and included details of the articles, patients, proton therapy dose regime and technique and measures for QOL or/and PRO. If comparisons were made to photon-based therapy, the treatment and patient characteristics for photon therapy were also extracted.

\section{Meta-analyses}

Due to the small number of eligible studies and studies from the same pool of patients reported by the same groups in multiple articles for different endpoints, meta-analysis is not warranted.

\section{RESULTS}

\section{Study selection and quality assessment}


The database queries produced 80 and 150 records from PubMed and Scopus, respectively (Fig. 1, Supplementary A). After removal of duplicates, 175 reports were reviewed for inclusion and 6 met the inclusion criteria [24-29]. In the second phase, where citations of the previously selected reports were reviewed using Scopus which is a source-neutral abstract and citation database, 240 articles were reviewed, and no additional papers were found. The included studies were found to be of reasonable quality with patients accrued in a centre which is expected due to the limited number of proton centres. Sample size and calculations were rarely mentioned.

\section{Characteristics of included studies}

Table 2 summarises the characteristics of the selected studies including 302 patients treated with proton and 438 patients treated with photon. Due to the possible overlap of patients across studies reported by the same research groups, the number of patients is likely to be an overestimation and we refrained from summing the number of patients in the preceding subsections. All studies reported prospectively collected outcome measurements. The publication dates ranged from 2016 to 2020 which reflect the recency of PT introductory into widespread practice and emphasis to PRO and QOL.

\section{Studies comparing proton therapy and photon radiotherapy}

Four studies presented the comparison between proton therapy and proton radiotherapy in term of QOL and PRO changes (Table 2). Blanchard et al. 2016 and Sio et al. 2016 compared the outcomes of proton therapy to patients treated with IMRT while more recent reports (Manzar et al. 2020 and Sharma et al. 2018) used patients treated with VMAT. Overall, in all QOL and PRO measures where the differences were significant, patients treated with proton therapy reported better outcomes including lesser xerostomia, lesser cough, lesser need for nutritional supplements, lesser dysgeusia, better food taste, better appetite, less mucous and better general symptoms.

\section{Effect of time}

In this review, we divided the time into several time points (Table 3); acute, subacute, late at $<1$ year and late at $\geq 1$ year. In comparison to patients treated with photon radiotherapy, 
patients treated with proton therapy have better outcomes across most time points. Sio et al. is the only report which included the outcome during treatment found no difference between the two treatment modalities. Blanchard et al. found the difference for xerostomia during subacute timepoint only and no difference was found during the late time points. Bagley et al. and Grant et al. found a similar pattern for xerostomia and dysphagia where the worst was during the treatment which improved during subacute and late phases. The scores, however, remained worse than baseline.

\section{Effect of dose factors}

Only one study performed an analysis of dose-outcome association which found a significant univariate association of oral cavity dose to xerostomia [28]. In multivariate analysis, the feature is no longer significant. Doses to multiple structures were found to receive a lower radiation dose in proton therapy compared to photon therapy reported by Sharma et al. and Manzar et al. which complement findings from other dose comparison studies for head and neck cancers [17, 25, 26, 30, 31].

\section{Effect of clinical factors}

The $\mathrm{T}$ and $\mathrm{N}$ stages, baseline status and time from the radiotherapy were found to be significant predictors for patient-reported and quality of life outcomes.

\section{DISCUSSION}

We conducted a systematic review to methodically accumulate and synthesize the evidence of patient-reported outcomes and quality of life changes following proton therapy of the oropharyngeal carcinoma. This is an improvement from a systematic review by Verma et al. which combined treatments of many diagnoses treated with proton therapy which provided a good breadth of the issue but not depth [32]. Furthermore, we found five new articles which fulfilled our inclusion criteria as compared to one described in Verma et al. in 2017 [32]. This is expected given the exponential growth of the number of reports due to the recent availability of proton therapy in many centres. Based on this systematic review, we found; 1) studies consistently showed the advantages of proton therapy compared to photon therapy, 2) studies showed a significant decline in functions following proton 
therapy at the acute stage which will improve and 3) functions do not revert to pretreatment status.

Six reports were included in this systematic review. However, four of which came from a single centre, MD Anderson Cancer Centre in Houston Texas. Furthermore, all centres reporting the outcomes were from the United States of America. The lack of reports from other centres is likely to be associated with the low number of centres which offer proton therapy for the treatment of oropharyngeal carcinoma. Only 109 proton therapy machines are now operational across the world from which 40 are located in the USA (dirac.iaea.org). To put this into perspective, more than 14000 high energy photon therapy machines are available across the globe. As 38 new centres are now under construction [33], more reports on treatment outcomes following proton therapy may come soon. Second, centres are likely to focus on provider-reported outcomes for toxicity following treatments of oropharyngeal carcinoma which are reported in several studies [34]. As the emphasis on PROs and QOL measures is increasing in recent years due to a paradigm change to increase the involvements of patients in decision-making and to capture outcomes which matter to patients [35], we are optimistic to see reports with larger cohorts from other centres across the globe.

Generally, the patient-reported outcomes and the quality-of-life measures favour proton therapy. This can be simply explained by the better dose distribution using proton therapy due to the beam characteristics as several dose comparison studies have observed the superiority of proton therapy as compared to photon [17, 30, 31]. The dose to the salivary gland and the larynx, structures commonly associated with increased risks of xerostomia and dysphagia, were found to be higher when VMAT or IMRT were utilised [30, 36]. However, the difference was only significant within the first year following treatment. The change for xerostomia was found to be no longer significant after the acute phase [24] and the number of domains remained significantly worse for photon therapy after the acute phase was also reduced [27, 37]. At least three hypotheses can be made from this observation. First, the higher dose received from photon therapy causes delayed recovery associated with a higher volume of tissue receiving low dose radiation, common in IMRT. Second, after the initial stage of quality of life changes following cancer treatment, patients 
may have adapted to the new norms and thus, reported less bother. Third, it should be noted that none of these studies randomised patients into proton or photon treatment arms. Consequently, bias due to systematic differences between patients treated with proton and photon therapy cannot be discounted and probably impacting future cost-effectiveness analysis [38].

The main drawback of proton therapy is the high cost associated with the construction of a cyclotron and maintenance of the facility. To put the comparison in perspective, the cost of proton therapy is approximately 2.4 times more than photon-based therapy. Frequently, the cost-effectiveness of proton therapy is being questioned [39]. Cost-effectiveness analysis showed that the use of IMPT was only cost-effective for a fraction of younger patients with a high risk of profound reduction of long-term morbidity [39]. To identify patients expected to benefit from proton therapy compared to IMRT, selection based on NTCP models has been implemented [40, 41]. In this strategy, planning comparisons between photon and proton therapy were performed on an individual level. The reduction in multivariable normal tissue complication probability (NTCP) models which numerically describes the relationship between the dose delivered to organs at risk and clinical factors and the predicted risk of radiation-induced side effects were then employed to detect whether PT is clinically advantageous. With this strategy, resources will be optimally utilised for the benefit of patients without straining the healthcare system. This NTCPbased method, however, is subject to model- and dose-related uncertainties [42]. Furthermore, the high cost can be financially problematic for countries with limited resources which further widen the gap of health disparities between countries [43-46]. Especially for treatment like oropharyngeal carcinoma where it is expected that only 0 to $0.4 \%$ probabilities that proton therapy was cost-effective for 65 - and 55-year old patients [39], its utilisation in low- and middle-income country is very likely to be societally unacceptable. Fortunately, the cost for proton therapy is continuously decreasing with more compact designs allowing space-related costs to be further minimised. The treatment delivery is also improving which may further reduce the dose to normal tissue [47].

We should note some limitations of the systematic review. First, a small number of the available study were conducted in a limited number of centres may limit the applicability 
medRxiv preprint doi: https://doi.org/10.1101/2020.11.04.20226175; this version posted November 6, 2020. The copyright holder for this preprint

(which was not certified by peer review) is the author/funder, who has granted medRxiv a license to display the preprint in perpetuity.

All rights reserved. No reuse allowed without permission.

of this review. Second, due to the lack of independence across studies, no meta-analyses can be performed. Third, it is acknowledged that selection bias where negative studies are less likely to be published and thus not be searchable may influence the observation.

\section{CONCLUSION}

Proton therapy may improve patient-reported and quality of life outcomes for patients treated for oropharyngeal carcinoma especially in acute and early late timepoints which improve in later time points. This observation can be proven or challenged as more data available as proton therapy becomes more widely available. 
medRxiv preprint doi: https://doi.org/10.1101/2020.11.04.20226175; this version posted November 6, 2020. The copyright holder for this preprint (which was not certified by peer review) is the author/funder, who has granted medRxiv a license to display the preprint in perpetuity.

All rights reserved. No reuse allowed without permission.

\section{Table Legends}

Table 1: Study characteristics

Table 2: Significant endpoints and significant factors impacting the endpoints

Table 3: Table 3: Significant endpoints based on the time points divided into acute, subacute, late at $<1$ year and late at $\geq 1$ year.

\section{Figure Legend}

Figure 1: Identification of inclusion based on PRISMA. Eligibility was determined using PICOS criteria (Supplementary A).

\section{Supplementary Materials}

Supplementary A: PICOS criteria for inclusion

Supplementary B: Search strategy using Pubmed and Scopus databases

Supplementary C: Quality check of selected studies 


\section{REFERENCES}

1. Høxbroe Michaelsen S, Grønhøj C, Høxbroe Michaelsen J, Friborg J, von Buchwald C. Quality of life in survivors of oropharyngeal cancer: A systematic review and meta-analysis of 1366 patients. European Journal of Cancer. 2017;78:91-102. doi: 10.1016/j.ejca.2017.03.006.

2. Sapir E, Tao Y, Feng F, Samuels S, El Naqa I, Murdoch-Kinch CA, et al. Predictors of Dysgeusia in Patients With Oropharyngeal Cancer Treated With Chemotherapy and Intensity Modulated Radiation Therapy. International Journal of Radiation Oncology*Biology*Physics. 2016;96(2):354-61. doi: 10.1016/j.ijrobp. 2016.05.011.

3. Dixon L, Ramasamy S, Cardale K, Dyker K, Garcez K, Lee LW, et al. Long term patient reported swallowing function following chemoradiotherapy for oropharyngeal carcinoma. Radiotherapy and Oncology. 2018;128(3):452-8. doi: 10.1016/j.radonc.2018.06.014.

4. Windon MJ, Fakhry C, Faraji F, Troy T, Gourin CG, Kiess AP, et al. Priorities of human papillomavirus-associated oropharyngeal cancer patients at diagnosis and after treatment. Oral Oncology. 2019;95:11-5. doi: 10.1016/j.oraloncology.2019.05.016.

5. Gabryś HS, Buettner F, Sterzing F, Hauswald H, Bangert M. Parotid gland mean dose as a xerostomia predictor in low-dose domains. Acta Oncologica. 2017;56(9):1197-203. doi: 10.1080/0284186x.2017.1324209.

6. Han P, Lakshminarayanan P, Jiang W, Shpitser I, Hui X, Lee SH, et al. Dose/Volume histogram patterns in Salivary Gland subvolumes influence xerostomia injury and recovery. Scientific Reports. 2019;9(1). doi: 10.1038/s41598-019-40228-y.

7. Kawamoto T, Nihei K, Nakajima Y, Kito S, Sasai K, Karasawa K. Comparison of xerostomia incidence after three-dimensional conformal radiation therapy and contralateral superficial lobe parotid-sparing intensity-modulated radiotherapy for oropharyngeal and hypopharyngeal cancer. Auris Nasus Larynx. 2018;45(5):1073-9. doi: 10.1016/j.anl.2018.01.010.

8. Mavroidis P, Price A, Fried D, Kostich M, Amdur R, Mendenhall W, et al. Dose-volume toxicity modeling for de-intensified chemo-radiation therapy for HPV-positive oropharynx cancer. Radiotherapy and Oncology. 2017;124(2):240-7. doi: 10.1016/j.radonc.2017.06.020.

9. Chera BS, Fried D, Price A, Amdur RJ, Mendenhall W, Lu C, et al. Dosimetric Predictors of Patient-Reported Xerostomia and Dysphagia With Deintensified Chemoradiation Therapy for HPVAssociated Oropharyngeal Squamous Cell Carcinoma. International Journal of Radiation Oncology*Biology*Physics. 2017;98(5):1022-7. doi: 10.1016/j.ijrobp.2017.03.034.

10. Vainshtein JM, Moon DH, Feng FY, Chepeha DB, Eisbruch A, Stenmark MH. Long-Term Quality of Life After Swallowing and Salivary-Sparing Chemo-Intensity Modulated Radiation Therapy in Survivors of Human Papillomavirus-Related Oropharyngeal Cancer. International Journal of Radiation Oncology*Biology*Physics. 2015;91(5):925-33. doi: 10.1016/j.ijrobp.2014.12.045.

11. Mogadas S, Busch CJ, Pflug C, Hanken H, Krüll A, Petersen C, et al. Influence of radiation dose to pharyngeal constrictor muscles on late dysphagia and quality of life in patients with locally advanced oropharyngeal carcinoma. Strahlentherapie und Onkologie. 2020;196(6):522-9. doi: 10.1007/s00066-019-01572-0.

12. Cui T, Ward MC, Joshi NP, Woody NM, Murray EJ, Potter J, et al. Correlation between plan quality improvements and reduced acute dysphagia and xerostomia in the definitive treatment of oropharyngeal squamous cell carcinoma. Head \& Neck. 2019;41(4):1096-103. doi: 10.1002/hed.25594. 
13. Mendenhall NP, Malyapa RS, Su Z, Yeung D, Mendenhall WM, Li Z. Proton therapy for head and neck cancer: Rationale, potential indications, practical considerations, and current clinical evidence. Acta Oncologica. 2011;50(6):763-71. doi: 10.3109/0284186x.2011.590147.

14. Beddok A, Vela A, Calugaru V, Tessonnier T, Kubes J, Dutheil P, et al. Protonthérapie des carcinomes épidermoïdes des voies aérodigestives supérieures: de la physique à la clinique. Cancer/Radiothérapie. 2019;23(5):439-48. doi: 10.1016/j.canrad.2019.05.015.

15. Simone CB, Ly D, Dan TD, Ondos J, Ning H, Belard A, et al. Comparison of intensitymodulated radiotherapy, adaptive radiotherapy, proton radiotherapy, and adaptive proton radiotherapy for treatment of locally advanced head and neck cancer. Radiotherapy and Oncology. 2011;101(3):376-82. doi: 10.1016/j.radonc.2011.05.028.

16. Kandula S, Zhu X, Garden AS, Gillin M, Rosenthal DI, Ang K-K, et al. Spot-scanning beam proton therapy vs intensity-modulated radiation therapy for ipsilateral head and neck malignancies: A treatment planning comparison. Medical Dosimetry. 2013;38(4):390-4. doi: 10.1016/j.meddos.2013.05.001.

17. Apinorasethkul O, Kirk M, Teo K, Swisher-McClure S, Lukens JN, Lin A. Pencil beam scanning proton therapy vs rotational arc radiation therapy: A treatment planning comparison for postoperative oropharyngeal cancer. Medical Dosimetry. 2017;42(1):7-11. doi: 10.1016/j.meddos.2016.09.004.

18. Håkansson K, Smulders B, Specht L, Zhu M, Friborg J, Rasmussen JH, et al. Radiation dosepainting with protons vs. photons for head-and-neck cancer. Acta Oncologica. 2020;59(5):525-33. doi: 10.1080/0284186x.2020.1714720.

19. Moreno AC, Frank SJ, Garden AS, Rosenthal DI, Fuller CD, Gunn GB, et al. Intensity modulated proton therapy (IMPT) - The future of IMRT for head and neck cancer. Oral Oncology. 2019;88:66-74. doi: 10.1016/j.oraloncology.2018.11.015.

20. Beddok A, Vela A, Calugaru V, Tessonnier T, Kubes J, Dutheil P, et al. Proton therapy for head and neck squamous cell carcinomas: A review of the physical and clinical challenges. Radiotherapy and Oncology. 2020;147:30-9. doi: 10.1016/j.radonc.2020.03.006.

21. Moher D, Liberati A, Tetzlaff J, Altman DG, Group P. Preferred reporting items for systematic reviews and meta-analyses: the PRISMA statement. BMJ. 2009;339:b2535. doi: 10.1136/bmj.b2535. PubMed PMID: 19622551; PubMed Central PMCID: PMCPMC2714657.

22. Yahya N, Chua X-J, Manan HA, Ismail F. Inclusion of dosimetric data as covariates in toxicity-related radiogenomic studies. Strahlentherapie und Onkologie. 2018;194(8):780-6. doi: 10.1007/s00066-018-1303-5.

23. Nattabi HA, Sharif NM, Yahya N, Ahmad R, Mohamad M, Zaki FM, et al. Is Diagnostic Performance of Quantitative 2D-Shear Wave Elastography Optimal for Clinical Classification of Benign and Malignant Thyroid Nodules? Academic Radiology. 2017. doi: 10.1016/j.acra.2017.09.002.

24. Blanchard P, Garden AS, Gunn GB, Rosenthal DI, Morrison WH, Hernandez M, et al. Intensity-modulated proton beam therapy (IMPT) versus intensity-modulated photon therapy (IMRT) for patients with oropharynx cancer - A case matched analysis. Radiotherapy and Oncology. 2016;120(1):48-55. doi: 10.1016/j.radonc.2016.05.022.

25. Manzar GS, Lester SC, Routman DM, Harmsen WS, Petersen MM, Sloan JA, et al. Comparative analysis of acute toxicities and patient reported outcomes between intensitymodulated proton therapy (IMPT) and volumetric modulated arc therapy (VMAT) for the treatment of oropharyngeal cancer. Radiotherapy and Oncology. 2020;147:64-74. doi: 10.1016/j.radonc.2020.03.010.

26. Sharma S, Zhou O, Thompson R, Gabriel P, Chalian A, Rassekh C, et al. Quality of Life of Postoperative Photon versus Proton Radiation Therapy for Oropharynx Cancer. Int J Part Ther. 
2018;5(2):11-7. Epub 2019/11/28. doi: 10.14338/IJPT-18-00032.1. PubMed PMID: 31773030; PubMed Central PMCID: PMCPMC6874189.

27. Sio T, Lin H-K, Shi Q, Gunn GB, Cleeland CS, Lee JJ, et al. Intensity Modulated Proton Therapy Versus Intensity Modulated Photon Radiation Therapy for Oropharyngeal Cancer: First Comparative Results of Patient-Reported Outcomes. International Journal of Radiation Oncology*Biology*Physics. 2016;95(4):1107-14. doi: 10.1016/j.ijrobp.2016.02.044.

28. Bagley AF, Ye R, Garden AS, Gunn GB, Rosenthal DI, Fuller CD, et al. Xerostomia-related quality of life for patients with oropharyngeal carcinoma treated with proton therapy. Radiother Oncol. 2020;142:133-9. Epub 2019/08/23. doi: 10.1016/j.radonc.2019.07.012. PubMed PMID: 31431373; PubMed Central PMCID: PMC31431373.

29. Grant SR, Hutcheson KA, Ye R, Garden AS, Morrison WH, Rosenthal DI, et al. Prospective longitudinal patient-reported outcomes of swallowing following intensity modulated proton therapy for oropharyngeal cancer. Radiotherapy and Oncology. 2020;148:133-9. doi: 10.1016/j.radonc.2020.04.021.

30. van de Water TA, Lomax AJ, Bijl HP, de Jong ME, Schilstra C, Hug EB, et al. Potential Benefits of Scanned Intensity-Modulated Proton Therapy Versus Advanced Photon Therapy With Regard to Sparing of the Salivary Glands in Oropharyngeal Cancer. International Journal of Radiation Oncology*Biology*Physics. 2011;79(4):1216-24. doi: 10.1016/j.ijrobp.2010.05.012.

31. Holliday EB, Kocak-Uzel E, Feng L, Thaker NG, Blanchard P, Rosenthal DI, et al. Dosimetric advantages of intensity-modulated proton therapy for oropharyngeal cancer compared with intensity-modulated radiation: A case-matched control analysis. Medical Dosimetry. 2016;41(3):189-94. doi: 10.1016/j. meddos.2016.01.002.

32. Verma V, Simone CB, Mishra MV. Quality of Life and Patient-Reported Outcomes Following Proton Radiation Therapy: A Systematic Review. JNCl: Journal of the National Cancer Institute. 2018;110(4):341-53. doi: 10.1093/jnci/djx208.

33. Group PTC-O. [26 July 2020]. Available from: ptcog.ch.

34. Gunn GB, Blanchard P, Garden AS, Zhu XR, Fuller CD, Mohamed AS, et al. Clinical Outcomes and Patterns of Disease Recurrence After Intensity Modulated Proton Therapy for Oropharyngeal Squamous Carcinoma. International Journal of Radiation Oncology*Biology*Physics. 2016;95(1):360-7. doi: 10.1016/j.ijrobp.2016.02.021.

35. Deshpande P, Sudeepthi B, Rajan S, Abdul Nazir CP. Patient-reported outcomes: A new era in clinical research. Perspectives in Clinical Research. 2011;2(4). doi: 10.4103/22293485.86879 .

36. Brodin NP, Kabarriti R, Pankuch M, Schechter CB, Gondi V, Kalnicki S, et al. A Quantitative Clinical Decision-Support Strategy Identifying Which Patients With Oropharyngeal Head and Neck Cancer May Benefit the Most From Proton Radiation Therapy. International Journal of Radiation Oncology*Biology*Physics. 2019;104(3):540-52. doi: 10.1016/j.ijrobp.2018.11.039.

37. Sharma S, Zhou O, Thompson R, Gabriel P, Chalian A, Rassekh C, et al. Quality of Life of Postoperative Photon versus Proton Radiation Therapy for Oropharynx Cancer. International Journal of Particle Therapy. 2018;5(2):11-7. doi: 10.14338/ijpt-18-00032.1.

38. Jones DA, Smith J, Mei XW, Hawkins MA, Maughan T, van den Heuvel F, et al. A systematic review of health economic evaluations of proton beam therapy for adult cancer: Appraising methodology and quality. Clinical and Translational Radiation Oncology. 2020;20:19-26. doi: 10.1016/j.ctro.2019.10.007.

39. Sher DJ, Tishler RB, Pham N-L, Punglia RS. Cost-Effectiveness Analysis of Intensity Modulated Radiation Therapy Versus Proton Therapy for Oropharyngeal Squamous Cell Carcinoma. International Journal of Radiation Oncology*Biology*Physics. 2018;101(4):875-82. doi: 10.1016/j.ijrobp.2018.04.018. 
medRxiv preprint doi: https://doi.org/10.1101/2020.11.04.20226175; this version posted November 6, 2020. The copyright holder for this preprint (which was not certified by peer review) is the author/funder, who has granted medRxiv a license to display the preprint in perpetuity.

All rights reserved. No reuse allowed without permission.

40. Jakobi A, Bandurska-Luque A, Stützer K, Haase R, Löck S, Wack L-J, et al. Identification of Patient Benefit From Proton Therapy for Advanced Head and Neck Cancer Patients Based on Individual and Subgroup Normal Tissue Complication Probability Analysis. International Journal of Radiation Oncology*Biology*Physics. 2015;92(5):1165-74. doi: 10.1016/j.ijrobp.2015.04.031.

41. Langendijk JA, Lambin P, De Ruysscher D, Widder J, Bos M, Verheij M. Selection of patients for radiotherapy with protons aiming at reduction of side effects: The model-based approach. Radiotherapy and Oncology. 2013;107(3):267-73. doi: 10.1016/j.radonc.2013.05.007.

42. Bijman RG, Breedveld S, Arts T, Astreinidou E, de Jong MA, Granton PV, et al. Impact of model and dose uncertainty on model-based selection of oropharyngeal cancer patients for proton therapy. Acta Oncologica. 2017;56(11):1444-50. doi: 10.1080/0284186x.2017.1355113.

43. Trajman A, Yahya N, Sukiman NK, Suhaimi NA, Azmi NA, Manan HA. How many roads must a Malaysian walk down? Mapping the accessibility of radiotherapy facilities in Malaysia. Plos One. 2019;14(3). doi: 10.1371/journal.pone.0213583.

44. Yahya N, Roslan N. Estimating radiotherapy demands in South East Asia countries in 2025 and 2035 using evidence-based optimal radiotherapy fractions. Asia-Pacific Journal of Clinical Oncology. 2018;14(5):e543-e7. doi: 10.1111/ajco.12831.

45. Atun R, Jaffray DA, Barton MB, Bray F, Baumann M, Vikram B, et al. Expanding global access to radiotherapy. The Lancet Oncology. 2015;16(10):1153-86. doi: 10.1016/s14702045(15)00222-3.

46. Barton MB, Frommer M, Shafiq J. Role of radiotherapy in cancer control in low-income and middle-income countries. The Lancet Oncology. 2006;7(7):584-95. doi: 10.1016/s14702045(06)70759-8.

47. van de Water TA, Lomax AJ, Bijl HP, Schilstra C, Hug EB, Langendijk JA. Using a Reduced Spot Size for Intensity-Modulated Proton Therapy Potentially Improves Salivary Gland-Sparing in Oropharyngeal Cancer. International Journal of Radiation Oncology*Biology*Physics. 2012;82(2):e313-e9. doi: 10.1016/j.jirobp.2011.05.005. 
Table 1: Study characteristics

\begin{tabular}{|c|c|c|c|c|c|c|c|c|c|}
\hline Reference & No. & $\begin{array}{l}\text { Stage } \\
\text { III/IV } \\
(\%)\end{array}$ & $\begin{array}{l}\text { \% HPV } \\
\text { positive } \\
\text { (+), } \\
\text { unknown } \\
\text { (?) }\end{array}$ & $\begin{array}{l}\text { Type of } \\
\text { proton } \\
\text { therapy }\end{array}$ & $\begin{array}{l}\text { Dose } \\
\text { (Gy } \\
\text { RBE) }\end{array}$ & $\begin{array}{l}\text { Other } \\
\text { treatments }\end{array}$ & $\begin{array}{l}\text { Therapy } \\
\text { comparison }\end{array}$ & $\begin{array}{l}\text { Details of } \\
\text { therapy } \\
\text { comparison }\end{array}$ & $\begin{array}{l}\text { QOL, } \\
\text { meas }\end{array}$ \\
\hline $\begin{array}{l}\text { Bagley } \\
2020\end{array}$ & 69 & $\begin{array}{l}\text { AJCC7 } \\
\text { stage } \\
\text { III-IV } \\
\text { MO - } \\
100\end{array}$ & $\begin{array}{l}+84 \\
? 14\end{array}$ & & $\begin{array}{l}\text { Median - } \\
69.3, \\
\text { range } \\
60-70\end{array}$ & $\begin{array}{l}\text { Induction -5, } \\
\text { concurrent - } \\
38, \\
\text { Induction + } \\
\text { concurrent - } \\
11\end{array}$ & - & - & $\begin{array}{l}\text { 15-it } \\
\text { Xero: } \\
\text { Relat } \\
\text { Scal } \\
\text { (XeQ }\end{array}$ \\
\hline $\begin{array}{l}\text { Blanchard } \\
2016\end{array}$ & 50 & $\begin{array}{l}\text { T3-T4 } \\
-20 \\
\text { N2-N3 } \\
-80\end{array}$ & $\begin{array}{l}+88 \\
? 10\end{array}$ & & $\begin{array}{l}\text { Small } \\
\text { volume } \\
\text { disease - } \\
66, \\
\text { advanced } \\
\text { disease - } \\
70\end{array}$ & $\begin{array}{l}\text { Concurrent - } \\
64 \%\end{array}$ & 100 IMRT & $\begin{array}{l}2: 1, \text { matched } \\
\text { laterality, site, } \\
\text { HPV, T and N } \\
\text { status, } \\
\text { smoking \& } \\
\text { chemotherapy }\end{array}$ & Not s \\
\hline $\begin{array}{l}\text { Grant } \\
2020\end{array}$ & 71 & $\begin{array}{l}\text { AJCC } \\
7 \text { th } \\
\text { edition } \\
\text { stage } \\
\text { III/IV - } \\
100\end{array}$ & $\begin{array}{l}+85.9 \\
? 7.0\end{array}$ & & $\begin{array}{l}\text { range - } \\
66-70 \text { Gy }\end{array}$ & $\begin{array}{l}\text { Induction -5, } \\
\text { concurrent - } \\
41, \text { induction + } \\
\text { concurrent - } \\
10,\end{array}$ & - & - & $\begin{array}{l}\text { MD f } \\
\text { Dysp } \\
\text { Inver }\end{array}$ \\
\hline $\begin{array}{l}\text { Manzar } \\
2020\end{array}$ & 46 & $\begin{array}{l}\text { AJCC } \\
7 \text { th } \\
\text { edition } \\
\text { Stage } \\
\text { III/IV - } \\
84.8\end{array}$ & $\begin{array}{l}+76.1 \\
? 13.0\end{array}$ & & $\begin{array}{l}\text { adjuvant, } \\
\text { range - } \\
60-66 ; \\
\text { definitive } \\
-70\end{array}$ & $\begin{array}{l}\text { Concurrent - } \\
36\end{array}$ & 259 VMAT & $\begin{array}{l}\text { Significant } \\
\text { difference: age } \\
\text { (IMPT older) } \\
\text { smoking } \\
\text { status and } \\
\text { pack-years } \\
\text { (VMAT } \\
\text { higher), dose } \\
\text { category } \\
\text { (more } \\
\text { definitive RT in } \\
\text { IMPT), }\end{array}$ & $\begin{array}{l}\text { EOR } \\
\text { H\&N: }\end{array}$ \\
\hline $\begin{array}{l}\text { Sharma } \\
2018\end{array}$ & 31 & \begin{tabular}{|l|} 
Stage \\
I-III - \\
13 IVA \\
\end{tabular} & $\begin{array}{l}\text { Not } \\
\text { stated }\end{array}$ & & $\begin{array}{l}\text { median - } \\
61.7\end{array}$ & $\begin{array}{l}\text { Chemotherapy } \\
-12\end{array}$ & 33 VMAT & $\begin{array}{l}\text { Median dose - } \\
62.6(\mathrm{~ns}) ; \\
\text { chemotherapy }\end{array}$ & $\begin{array}{l}\text { QLQ. } \\
\text { versi } \\
\text { EOR }\end{array}$ \\
\hline
\end{tabular}




\begin{tabular}{|c|c|c|c|c|c|c|c|c|}
\hline & & -87 & & & & & $-14(\mathrm{~ns})$ & $\begin{array}{l}\text { H\&N: } \\
\text { the C } \\
\text { (GRl: } \\
\text { Xero: } \\
\text { Work } \\
\text { and } \\
\text { Perfc } \\
\text { Statu } \\
\text { Heac } \\
\text { Neck } \\
\text { ques }\end{array}$ \\
\hline Sio 2016 & 35 & $\begin{array}{l}\text { Stage } \\
\text { III-IV - } \\
94.3\end{array}$ & $\begin{array}{l}+74.3 \\
? 20\end{array}$ & $\begin{array}{l}\text { median } \\
70.0, \\
\text { range - } \\
59.0-70.0\end{array}$ & $\begin{array}{l}\text { concurrent } \\
\text { chemotherapy } \\
- \text { all, induction } \\
-26\end{array}$ & 46 IMRT & $\begin{array}{l}\text { Significant } \\
\text { difference: } \\
\text { location (more } \\
\text { tonsil), T-stage } \\
\text { (more T3-T4), } \\
\text { lower } \\
\text { induction } \\
\text { chemotherapy, } \\
\text { higher total } \\
\text { radiation dose }\end{array}$ & $\begin{array}{l}\text { MD f } \\
\text { Symr } \\
\text { Inver } \\
\text { Heac } \\
\text { Neck } \\
\text { (MD f } \\
\text { top 1 } \\
\text { sevel }\end{array}$ \\
\hline
\end{tabular}

Table 2: Significant endpoints and significant factors impacting the endpoints

\begin{tabular}{|l|l|l|l|l|}
\hline Reference & Significant endpoints & $\begin{array}{l}\text { Non-significant } \\
\text { endpoints }\end{array}$ & $\begin{array}{l}\text { Significant clinical } \\
\text { factors }\end{array}$ & Do \\
\hline $\begin{array}{l}\text { Bagley } \\
2020\end{array}$ & $\begin{array}{l}\text { General xerostomia including } \\
\text { physical, personal, pain, and social } \\
\text { domains }\end{array}$ & - & $\begin{array}{l}\text { Time, } \\
\text { baseline XeQoLS } \\
\text { score, stage and N } \\
\text { status }\end{array}$ & Uni \\
\hline $\begin{array}{l}\text { Blanchard } \\
2016\end{array}$ & $\begin{array}{l}\text { Xerostomia at 3 months (favours } \\
\text { IMPT) }\end{array}$ & $\begin{array}{l}\text { Fatigue and } \\
\text { xerostomia at 1 year. }\end{array}$ & Not studied & No \\
\hline $\begin{array}{l}\text { Grant } \\
2020\end{array}$ & Composite score for dysphagia & - & T-stage & No \\
\hline
\end{tabular}




\begin{tabular}{|c|c|c|c|}
\hline $\begin{array}{l}\text { Manzar } \\
2020\end{array}$ & $\begin{array}{l}\text { Overall: Cough, need for nutritional } \\
\text { supplements and dysgeusia } \\
\text { (favour IMPT). } \\
\text { Subgroup analyses: Adjuvant - } \\
\text { Cough, sense of smell/taste and } \\
\text { problems with teeth, (favour IMPT) } \\
\text { and sexual symptoms (favour } \\
\text { IMRT). } \\
\text { Definitive - Feeling ill, feeding tube, } \\
\text { sense of smell/taste \& nutritional } \\
\text { supplements (favour IMPT). } \\
\text { Bilateral - Cough \& nutritional } \\
\text { supplements (favour IMPT) } \\
\text { Unilateral - dry mouth, } \\
\text { sticky saliva \& sense of smell/taste } \\
\text { (favour IMPT). } \\
\text { Concurrent chemotherapy - } \\
\text { swallow, nutritional supplements, } \\
\text { feeling ill \& sense of smell/taste } \\
\text { (favour IMPT) } \\
\text { RT only - cough } \\
\text { sense of smell/taste \& } \\
\text { problems with teeth (favour IMPT) } \\
\text { \& swallow (favour IMRT) }\end{array}$ & $\begin{array}{l}\text { EORTC H\&N QLQ-35 } \\
\text { questions not stated in } \\
\text { the previous cell }\end{array}$ & Not studied \\
\hline $\begin{array}{l}\text { Sharma } \\
2018\end{array}$ & $\begin{array}{l}3 \text { months - dental problem } \\
6 \text { months - moderate-to-severe dry } \\
\text { mouth, xerostomia day, xerostomia } \\
\text { night, dental problems, physical } \\
\text { function, role function. } \\
12 \text { months - H\&N pain, } \\
\text { xerostomis, moderate-severe dry } \\
\text { mouth, role function. }\end{array}$ & $\begin{array}{l}\text { Fatigue, sticky saliva } \\
\text { (day general) and } \\
\text { global health and } \\
\text { timepoints not stated in } \\
\text { the previous cell }\end{array}$ & Not studied \\
\hline Sio 2016 & $\begin{array}{l}\text { Symptom score - subacute phase } \\
\text { - food taste and appetite } \\
\text { Chronic phase - appetite (all } \\
\text { favour IMPT) } \\
\text { moderate to severe symptoms - } \\
\text { subacute phase - food taste and } \\
\text { mucus (favour IMPT) } \\
\text { mean of top } 5 \text { MDASI higher during } \\
\text { subacute phase for IMRT }\end{array}$ & $\begin{array}{l}\text { Other top } 11 \\
\text { symptoms - Dry mouth, } \\
\text { swallowing/chewing, } \\
\text { fatigue, pain, sleep, } \\
\text { mouth sores, } \\
\text { drowsiness, distress. }\end{array}$ & Not studied \\
\hline
\end{tabular}

